\title{
Effect of Processing Treatment on Physicochemical Characteristics of Brown Rice Varieties with Different Amylose Content
}

\author{
Jong Gu Lee and Moo-Hyeog Im* \\ Ministry of Food and Drug Safety
}

\begin{abstract}
The quality characteristics of brown rice polished with grains of four rice varieties (Hwaseonchal, Baegjinju, Ilpum and Goami) were examined. For the physical properties of native and fried brown rice starches, the gelatinization temperatures and enthalpies (determined with differential scanning calorimetry) of brown rice starches decreased with increasing amylose content. The pasting viscosities of native brown rice starches in distilled water were higher than those in $\mathrm{HgCl}_{2}$ solution (as an $\alpha$-amylase inhibitor). The highest viscosity of gelatinized starch was observed for the starch of Ilpum rice variety relative to other varieties. Cystal packing arrangement of brown rice starches subjected to deep-fat frying converted A-type (typically observed for cereal starches) into V-type (formed by retrogradation and recrystllization of amylose molecules).
\end{abstract}

Keywords: amylose content, amyloviscograph, brown rice, frying treatment, parboiling treatment

\section{서 론}

쌀은 우리나라의 주식으로 이용되는 곡류로서 영양학적으로 균 형 잡힌 완전식품이다. 쌀의 겉껍질만을 제거한 현미는 백미에 비하여 지방, 단백질, vitamin $\mathrm{B}_{1}, \mathrm{~B}_{2}$ 가 풍부하고, 식이섬유 함량 이 약 2 배정도 높으며 칼슘과 철분을 비롯한 각종 무기질의 함 량도 높기 때문에 현미를 백미로 도정할 때 도정도가 높아질수 록 양적 감소뿐만 아니라 호분층에 다량 함유되어 있는 각종 영 양분의 감소를 초래하게 된다고 한다(1). 우리나라에서는 쌀 입 식의 형태인 밥으로 주로 이용되며 가공품으로서 떡, 한과 등으 로 이용된다. 그러나, 서구화에 길들여진 현대인의 미각에는 그 다지 선호되지 않으며 영양개선을 목적으로 소비가 유지되고 있 다(2). 그리고 본 실험의 가공 과정 중 파보일링 처리는 인도에 서 처음 기원한 것으로서 현재 세계에서 유통되는 쌀의 대부분 파보일링 처리법을 이용하고 있다 $(3,4)$. 파보일링 처리는 쌀의 물 리적인 변화를 가져오며, 특히 수분 함량, 온도 등 여러 조건에 의해서 투명도, 도정율, 팽윤성, 용해도, 점성, 비타민, 당, 아미노 산 함량 등에 변화를 가져온다고 한다(4). 아밀로오스 함량은 쌀 의 조리특성과 밥의 조직감이나 광택 등 기호도를 결정하는 가 장 중요한 인자라고 하는 보고도 있다. 현대인들이 많이 선호하 는 튀김처리는 전분 호화, 단백질 변성 등의 반응을 일으킨다. 이 는 가장 중요한 식품 조리법의 한 방법이며 우리나라뿐만 아니

*Corresponding author: Moo-Hyeog Im, Ministry of Food and Drug Safety, Cheongwon, Chungbuk 363-704, Korea

Tel: 82-2-719-2020

Fax: 82-2-382-4892

E-mail: imh0119@korea.kr

Received May 29, 2013; revised July 30, 2013;

accepted July 30, 2013
라 세계에서도 역사가 오래되었고, 폭넓게 이용되며 이런 추세는 향후에도 지속될 것으로 예상된다 $(5,6)$. 이런 튀김공정은 탈수에 의해 생성된 표면 조직의 조직감, 흡수된 지방의 부드러운 맛 및 독특한 향, 그리고 보존성의 연장 등에 기인하여 패스트푸드의 급속한 발전을 가져왔다(7). 현재 곡류를 이용한 시리얼 푸드는 식생활의 다양화에 따라 시판 중인 제품들은 많으나 튀김처리에 대한 연구는 미흡한 실정이다. 그래서 본 연구에서는 쌀의 아밀 로오스 함량이 다른 품종들을 선정하여 튀김처리에 따른 품종별 이화학적 특성을 비교하여 현대인의 기호도를 높일 수 있는 가 공적성에 대한 기초자료를 제공하고자 한다.

\section{재료 및 방법}

\section{실험 재료}

본 시험에 사용한 재료는 농촌진흥청 작물시험장에서 생산된 화선찰벼(Hwaseonchalbyeo, Suwon 348, amylose 0\%), 백진주벼 (Baegjinjubyeo, Suwon 460, amylose 9.1\%), 일품벼(Ilpumbyeo, 수원 355호, amylose 18.9\%), 고아미벼(Goamibyeo, Milyang 168, $27.5 \%$ )를 분양 받아 공시재료로 사용하였으며, 튀김유는 (주)오뚜 기의 식물성 유지 쇼트닝을 사용하였다.

\section{가공 처리 방법}

파보일링 처리는 예비실험으로 아밀로오스 함량이 다른 4 가지 품종 즉, 화선찰벼, 백진주벼, 일품벼, 고아미벼를 각각 $10 \mathrm{~g}$ 을 30 , 45 및 $60^{\circ} \mathrm{C}$ 의 증류수에 침지시켜 시간의 경과에 따라 경시적으로 채취하여 여과지 위에 굴려서 표면수를 제거한 후 무게 증가량으 로부터 건물 $10 \mathrm{~g}$ 중 수분증가량과 품종별 현미 전분의 호화 개 시 온도, 최고점도온도 등을 알기 위해 amyloviscograph를 측정하 였다. 그 결과 품종에 따른 전분의 호화개시온도가 $60-65^{\circ} \mathrm{C}$ 의 범 
위를 나타내었다(8). 수분흡수에 따른 외형의 변화, 호화개시온도 와 최고점도 온도 등의 결과를 바탕으로 파보일링 처리 조건을 $60^{\circ} \mathrm{C}$ 의 증류수에 60 분간 수침시키는 것으로 설정하였다. 튀김 처 리 온도의 설정은 튀김 처리를 통해 내부로 열이 전달되는 속도 와 식품 표면에서 물이 증발되는 속도의 균형이 이뤄지도록 해야 한다. 튀김 처리 온도는 일반적으로 $195^{\circ} \mathrm{C}$ 이하에서 튀기는 것이 적당하다고 알려져 있는데, 이것은 그 이상의 온도에서는 열안정 성이 급격히 감소하기 때문이다(9). 이를 참고하여 아밀로오스 함 량이 다른 4가지 품종 즉, 화선찰벼, 백진주벼, 일품벼, 고아미벼 를 각각 건부 중량 기준으로 하여 파보일링 처리, 수분함량을 10 , $15,20,25,30,35,40$ 및 45\%, 튀김온도 $160,170,180,190$ 및 $195^{\circ} \mathrm{C}$ 로 예비실험 조건 설정을 하였다. 처리구는 튀김 처리 후 외 형의 변화, 색도와 식미 검사를 통하여 색깔과 조직감이 우수한 $190^{\circ} \mathrm{C}$ 에서 $30 \mathrm{sec}$ 로 설정하였으며, 튀김 처리 직후 기름을 제거하 고 산화방지를 위하여 밀봉하여 시료로 사용하였다.

\section{시차주사 열량계에 의한 특성}

전분의 열역학적 특성은 시차주사 열량계 (Perkin Elmer DSC7, Waltham, MA, USA)을 사용하여 분석하였으며 온도와 엔탈피 의 보정은 indium (m.p $156.6^{\circ} \mathrm{C}, \Delta \mathrm{H}_{\mathrm{m}} 28.5 \mathrm{~J} / \mathrm{g}$ )을 사용하였으며 시료의 가열은 $25-120^{\circ} \mathrm{C}$ 의 온도범위로 분당 $10^{\circ} \mathrm{C}$ 로 가열하였다. 전분 $20 \mathrm{mg}$ 을 무게를 측정한 후 Perkin Elmer사의 고압 스테인 레스 pan (0319-0218)에 담고 시료 건부 중량의 2배가 되도록 증 류수 $40 \mu \mathrm{L}$ 를 micropipet으로 첨가하고 sealer을 사용하여 밀봉한 다음 최종 무게를 확인하고 수분 평형에 도달할 수 있도록 2시 간 동안 상온에서 방치하였다. Reference pan으로는 sample pan 과 열 용량의 균형을 맞추기 위하여 빈 pan을 사용하였다. 가열 후 pan의 붕괴 유무를 알아보기 위하여 무게를 재어 가열 전과 비교하였으며 호화 엔탈피는 $\mathrm{J} / \mathrm{g}$ starch로 표시하였으며, 3회 반 복 측정하여 평균값을 사용하였다.

\section{증류수와 $\mathrm{HgCl}_{2}$ 에 따른 amyloviscograph}

Visco amylograph는 시료를 $100 \mathrm{mesh}$ 체로 친 것을 사용하였으 며(10), 전분농도를 건물 중량의 $8 \%$ 로 제조하여 $\mathrm{AACC}(11)$ 방법 에 의하여 amylograph (Visco-Amylo-Graph, Brabender $\mathrm{GmBH}$ Co., Duisburg, DE, Germany)를 사용하여 분석하였다. 온도를 $25^{\circ} \mathrm{C}$ 에서부터 $95^{\circ} \mathrm{C}$ 까지 $1.5^{\circ} \mathrm{C} / \mathrm{min}$ 의 속도로 승온 시키면서 점도 를 측정하였다. 측정개시온도는 $25^{\circ} \mathrm{C}$ 부터 시작하여 호화개시 온 도, 최고점도 온도 및 최고점도, Breakdown, Setback의 특성 값을 측정하였다. 호화개시 온도는 초기점도가 10 B.U.에 도달하는 온 도로 나타내었다. $95^{\circ} \mathrm{C}$ 에서 15 분간 유지시켰다가 다시 $1.5^{\circ} \mathrm{C} / \mathrm{min}$ 의 속도로 $50^{\circ} \mathrm{C}$ 까지 냉각시켰다.

\section{수분흡수지수(WAI), 수분용해도지수(WSI)}

WAI (water absorption index)값과 WSI (water solubilitity index)값 을 Anderson의 방법(12)으로 측정하였다. 쌀가루 시료 $2.5 \mathrm{~g}$ 에 $30 \mathrm{~mL}$ 의 증류수를 넣고 원심 분리관에서 분산시키고 가끔 흔들 어 주면서 실온에서 24 시간 방치한 다음 $3,000 \times \mathrm{g}$ 에서 10 분간 원 심 분리하였다. 상등액은 미리 함량을 구한 다음 수분 정량 수기 에서 건조하여 고형분량을 WSI로 산출하였으며 침전물의 무게 를 측정하여 $\mathrm{WAI}$ 를 산출하였으며, 3 회 반복 측정하여 평균값을 사용하였다.

\section{X선 회절도(X-ray diffractometer)에 의한 결정화도}

일품벼를 서로 다른 조건에서 처리한 5 가지의 백미와 현미 시
료를 X-선 회절상을 X-선 회절기(D/MAX-2500, Rigaku Co., Tokyo, Japan)를 사용하여 회절각도 $2 \theta=3-40^{\circ}$ 로 3 반복으로 Table 1 의 조건으로 회절도를 얻어 각 전분들의 결정성을 관찰하였다.

\section{현미가루 및 튀김 쌀의 미세구조(SEM) 관찰}

쌀가루의 입자상태와 튀김 쌀의 표면상태를 관찰하기 위하여 각각의 시료를 동결 건조 시킨 뒤 gold-palladium으로 도금하여 주사전자 현미경(PRISM07, Scanning Electron Microscope, Zeiss, Germany)으로 $20 \mathrm{kV}$ 의 가속전압에서 600 배율로 관찰하였다.

\section{재료 및 제품의 색도}

재료와 제품의 색도는 Chromameter CR 300 (Minolta Co., Osaka, Japan)을 사용하여 시료를 마쇄하여 측정하였고 Hunter system에 의하여 명도(L, lightness), 적색도(a, redness), 황색도(b, yellowness) 값으로 나타내었다. L값은 0(검정색)에서 100(흰색)까 지, $\mathrm{a}$ 값(적색도)은 -80 (녹색)에서 100 (적색)까지, $\mathrm{b}$ 값(황색도)은 70 (청색)에서 70 (황색)까지 측정하였다. 이때 사용한 표준판은 $\mathrm{L}=97.51, \mathrm{a}=-0.18, \mathrm{~b}=+1.67$ 의 값을 가진 백색판을 사용하였다.

\section{조직감 측정}

튀김 쌀의 조직감을 알아보기 위한 조직감 측정은 Rheometer (CR-200D, Sun Scientific Co. Ltd., Tokyo, Japan)를 사용하여 경 도, 응집성, 탄력성, 점착성 및 파쇄성을 3 회 반복 측정하여 평균 값을 사용하였다.

\section{결과 및 고찰}

\section{시차주사 열량계(DSC)법에 의한 특성}

아밀로오스 함량 차이가 있는 품종별 현미의 용융 흡열 곡선 을 관찰한 결과 아밀로오스 함량이 증가할수록 호화 엔탈피가 $11.83 \mathrm{~J} / \mathrm{g}$ 에서 $6.91 \mathrm{~J} / \mathrm{g}$ 까지 감소하는 경향을 나타내었으나 호화 양상은 품종별로 다르게 나타났다. Table 1에서 알 수 있는 바와 같이 amyloviscograph으로 구한 호화 개시온도보다는 다소 낮게 측정되었으며, 아밀로오스 함량에 따른 현미의 호화개시온도는 아밀로오스 함량이 증가할수록 $64.55,64.65,62.95$ 및 $60.52^{\circ} \mathrm{C}$ 로 감소하는 경향을 보였다. 이 결과는 이화학적 성질이 다른 쌀 전 분의 DSC 실험에서 호화 엔탈피와 호화온도가 유의한 상관관계 를 나타낸다고 하는 보고(13)와 유사한 결과를 나타내었다.

\section{증류수와 $\mathrm{HgCl}_{2}$ 에 따른 amyloviscograph}

아밀로오스 함량 차이가 있는 품종별 현미를 증류수와 현미 중

Table 1. Thermal gelatinization characteristics of several cultivar brown rice flours

\begin{tabular}{|c|c|c|c|c|c|}
\hline & \multicolumn{5}{|c|}{$\begin{array}{c}\text { Transition temperatures }\left(\mathrm{T},{ }^{\circ} \mathrm{C}\right) \text { and } \\
\text { transition enthalpies }(\Delta \mathrm{H}, \mathrm{J} / \mathrm{g} \text { dry matter })\end{array}$} \\
\hline & $\mathrm{T}_{\mathrm{i}}$ & $T_{p}$ & $\mathrm{~T}_{\mathrm{c}}$ & $\Delta \mathrm{H}$ & Onset \\
\hline A & 54.66 & 74.09 & 91.31 & 11.83 & 64.55 \\
\hline B & 49.75 & 73.40 & 91.71 & 10.74 & 64.65 \\
\hline $\mathrm{C}$ & 54.20 & 72.15 & 86.32 & 9.06 & 62.95 \\
\hline D & 55.85 & 69.01 & 80.88 & 6.91 & 60.52 \\
\hline
\end{tabular}

A: Hwaseonchalbyeo, B: Baegjinju, C: Ilpumbyeo, D: Goami. $\mathrm{T}_{\mathrm{i}}$ : Initial gelatinization temperature, $\mathrm{T}_{\mathrm{p}}$ : Peak gelatinization temperature, $\mathrm{T}_{\mathrm{c}}$ : Closed gelatinization temperature, $\Delta \mathrm{H}$ : Transition enthalpy for starch gelatinization 
Table 2. Amylograph characteristics of different cultivars determined by mixing with water or $\mathrm{HgCl}_{2}$ treated water

\begin{tabular}{cccccccc}
\hline Brown rice & S.T. ${ }^{1)}\left({ }^{\circ} \mathrm{C}\right)$ & G.T. $^{2)}\left({ }^{\circ} \mathrm{C}\right)$ & M.T. ${ }^{3)}\left({ }^{\circ} \mathrm{C}\right)$ & M.V.) $($ B.U. $)$ & B.D. (B.U.) & S.B. (B.U.) & T.S.B. (B.U.) \\
\hline A & 25 & - & - & - & - & - & - \\
B & 25 & 81.3 & 92.5 & 80 & 20 & 10 & 30 \\
C & 25 & 89.5 & 95.5 & 240 & 80 & 200 & 280 \\
D & 25 & - & - & - & - & - & - \\
E & 25 & 67 & 74.5 & 440 & 160 & -70 & 90 \\
F & 25 & 70 & 81 & 560 & 325 & 170 & 155 \\
G & 25 & 88 & 95.5 & 410 & 190 & - & -260 \\
H & 25 & - & - & - & - & - & - \\
\hline
\end{tabular}

S.T.: Starting temperature, G.T.: Gelatinization temperature, M.T.: Temperature at maximum viscosity, M.V.: Maximum viscosity, B.D.: Breakdown, S.B.: Setback, T.B.S.: Total setback.

A: Hwaseonchalbyeo, B: Baegjinju, C: Ilpumbyeo, D: Goami, E: Hwaseonchalbyeo treated $\mathrm{HgCl}_{2}$, F: Baegjinju treated $\mathrm{HgCl}$, G: Ilpumbyeo treated $\mathrm{HgCl}_{2}$, $\mathrm{H}$ : Goami treated $\mathrm{HgCl}_{2}$

Table 3. Water absorption index (WAI), water solubility index (WSI) and water retention capacity of rice flours (unit: \%)

\begin{tabular}{ccccc}
\hline & \multirow{2}{*}{ WAI } & WSI & \multicolumn{2}{c}{ Water holding capacity } \\
\cline { 3 - 5 } & & & Alkaline solution & Distilled water \\
\hline A & 214.53 & 0.15 & 134.25 & 114.07 \\
B & 213.29 & 0.14 & 133.46 & 111.06 \\
C & 208.73 & 0.12 & 121.76 & 106.46 \\
D & 207.23 & 0.11 & 119.77 & 104.12 \\
\hline
\end{tabular}

A: Brown Hwaseonchalbyeo. B: Brown Baegjinju. C: Brown Ilpumbyeo. D: Brown Goami.

효소의 불활성화를 위해서 $0.001 \mathrm{M} \mathrm{HgCl}$ 에 각각 희석하여 amylo graph를 측정한 결과 Table 2에서 보는 바와 같이 A, G, H는 B.U 값이 너무 낮게 나타나 호화 온도, breakdown, setback 등의 측정 이 불가능하였다. 이것은 $\operatorname{Damir}(14)$ 의 연구에 따르면 온도 상승 에 따라 호화 후 전분의 팽윤력이 커서 전분 입자들이 붕괴되어 점성 생성능력을 상실했거나 $\alpha$-amylase활성이 너무 강해서 분해 정도가 매우 큰 경우라고 한다. 호화온도는 $\mathrm{HgCl}_{2}$ 처리구가 무 처리구보다 낮은 경향을 보였고, 점도는 전분입자의 팽윤정도, 팽 윤된 전분 입자의 열과 전단에 대한 저항도, 가열된 입자로부터 용출된 가용성 전분, 그리고 팽윤된 입자들의 상호작용 또는 응 집성 등에 따라 영향을 받는데 $\mathrm{C}$ 가 가장 높은 것으로 나타났다. $\mathrm{B}$ 가 점성 유지능력이 가장 큰 것으로 나타났고, $\mathrm{D}$ 에서 점도와 breakdown 값이 가장 높은 수치를 보여주었다. 점도와 breakdown 값은 $\mathrm{HgCl}_{2}$ 처리구가 무처리구보다 매우 높은 결과를 보였다. 이 것은 전분입자의 팽윤정도가 증가하고, 팽윤 입자의 저항정도가 커졌음과 동시에 $\mathrm{HgCl}_{2}$ 를 처리함으로서 점도붕괴도 즉, 팽윤입 자의 붕괴 정도가 증가했다는 것을 나타낸다. 그리고, setback의 경우는 품종과 $\mathrm{HgCl}_{2}$ 처리 유무와는 상관관계가 없는 것으로 나 타났다.

\section{현미 품종에 따른 수분흡수지수(WAI), 수분용해도지수(WSI), 보수력(WHC)}

Table 3에서 보는 바와 같이 아밀로오스 함량이 높을수록 수분 흡수지수, 수분용해도지수 모두 낮아지는 경향을 나타내었다. 수 분흡수지수는 214.53 에서 207.23까지 품종에 따라 감소하는 것을 보여주었고, 수분용해도지수는 감소하는 경향은 같으나 품종간 차이는 없는 것으로 확인되었다. 그리고, 수분유지능력도 아밀로 오스 함량이 높을수록 감소되는 경향을 나타내었다.

\section{X선 회절도(X-ray diffractometer)에 의한 결정화도}

쌀을 고온에서 튀긴 후 $\mathrm{X}$-선 회절도 분석 결과 쌀 전분의 결 정형은 일품 백미 튀김의 경우 $2 \theta=20^{\circ}$ 에서 피크를 나타내는 결 정형이 거의 소실된 $\mathrm{V}$ 형에 가까운 모양이 관찰되었고, 일품 현 미의 경우 $14.6,16.4,17.8,22.9^{\circ}$ 에서 강한 피크를 보이는 $\mathrm{B}$ 형의 결정체에 가까웠고, 튀김 처리, 뻥튀기, 일품 백미는 모두 결정형 이 소실된 $\mathrm{V}$ 형을 나타내었다. 일반적으로 생전분의 $\mathrm{X}$ 선 회절도 에 의한 결정형이 $\mathrm{A}$ 형인 곡류 전분도 호화된 다음 결정화되면 $\mathrm{B}$ 형으로 변화되며 이것은 전분의 호화에 의해 사라졌던 결정형 이 노화되면서 $\mathrm{B}$ 형의 결정형으로 새로이 생성된다고 한다(10). 전분을 구성하는 아밀로오스와 아밀로펙틴은 두 단계로 노화과 정에 참여하는데 1 단계에서는 아밀로오스가 빠른 속도로 노화되 며, 2단계에서는 아밀로펙틴이 서서히 노화된다(15). 노화된 전분 을 다시 가열하면 아밀로오스는 비가역적 변화가 일어나며, 아밀 로펙틴은 가역적으로 변화되므로 노화의 결정형에 영향을 주는 것은 아밀로오스이며 이것은 아밀로오스 $\mathrm{X}$ 선 회절양상과 일치하 는 양상을 보여주었다.

\section{주사 전자 현미경(SEM)에 의한 특성}

원상태의 현미와 고온에 의한 전분의 형태학적 특성을 주사전 자현미경을 이용하여 관찰하였다. Fig. 1에서 보는 바와 같이 파 보일링 처리 즉, 호화 시킨 후 튀긴 처리구들은 아밀로오스 함량 이 높을수록 표면이 둥근 형태를 보임을 알 수 있다. 즉, 아밀로 오스 함량이 낮은 화선찰벼와 백진주벼는 아밀로오스 함량이 높 은 일품벼와 고아미벼에 비교해볼 때 표면이 다소 침식되어 있 는 것이 관찰되었다. 물리적인 힘을 가하지 않은 품종간에는 큰 차이가 없는 것으로 봐서 아밀로오스 함량과는 무관하다는 결론 을 내릴 수 있었다. 그리고, 입자 크기를 튀김 처리 여부로서 관 찰해본 결과 $\mathrm{A}$ 는 $100-1,000 \mu \mathrm{m}, \mathrm{C}$ 는 20-1,200 $\mu \mathrm{m}, \mathrm{E}$ 는 20-2,000 $\mu \mathrm{m}, \mathrm{G}$ 는 $20-1,000 \mu \mathrm{m}, \mathrm{I}$ 는 20-800 $\mu \mathrm{m}$ 정도임을 확인 할 수 있었 다. 또한, 뺑튀기 처리구는 수침 또는 호화에 따른 차이점은 없 는 것으로 판단되었으며 전체적으로 볼 때 튀김 처리 후가 무처 리에 비해서 2-12배 정도까지 부피가 증가하는 것을 알 수 있었 다. 뺑튀기의 경우 수침처리만 한 것의 외형은 누에고치와 유사 한 둥근 외형이 관찰되었으며, 수침 후 호화처리를 한 것의 외형 은 표면이 많이 깎여져 있는 것이 관찰되었다. 아밀로오스 함량 이 높을수록 팽화 부피는 증가하였으며, 무처리구와 튀김 처리구 를 비교해 볼 때 후자의 팽윤 정도가 훨씬 크다는 것을 확인 할 수 있었다. 


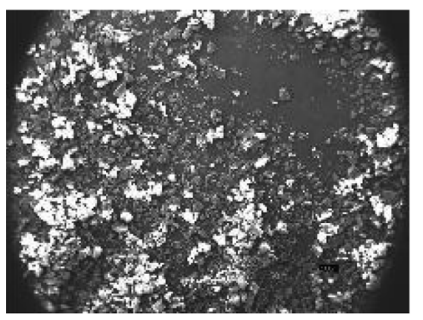

A

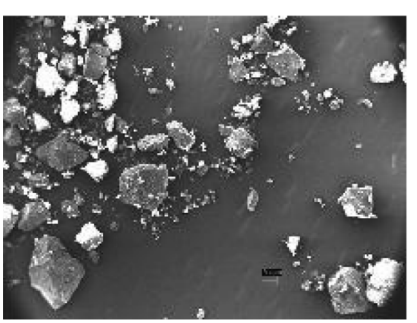

E

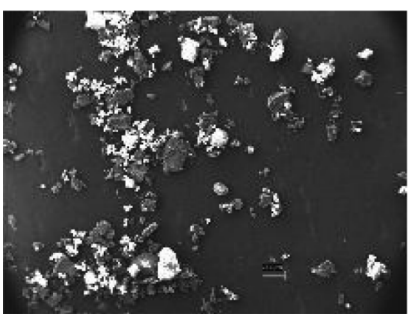

I

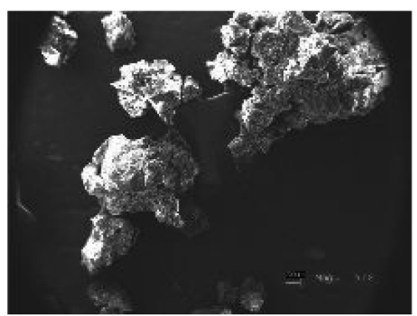

B

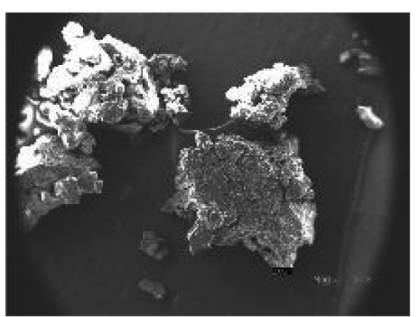

F

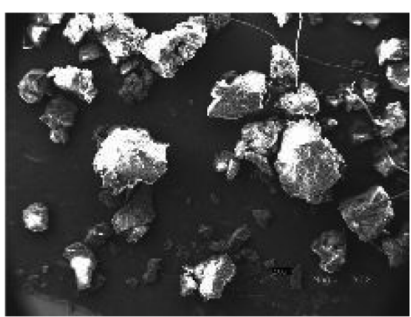

J

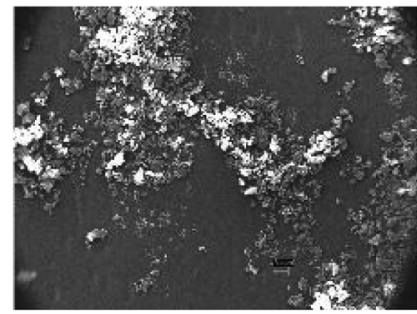

C

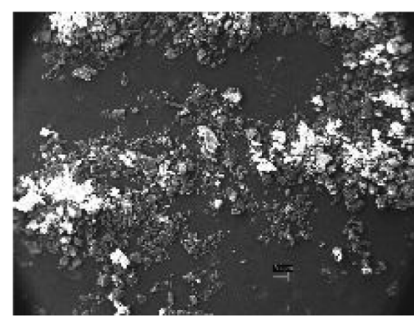

G

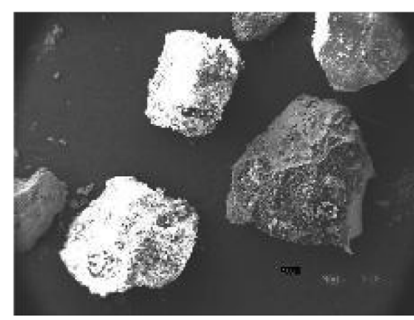

K

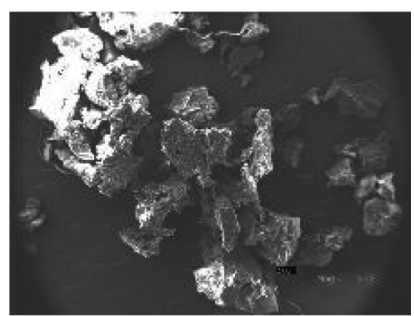

D

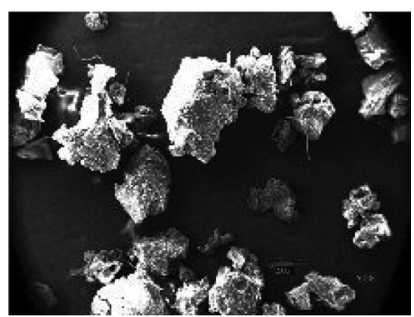

$\mathrm{H}$

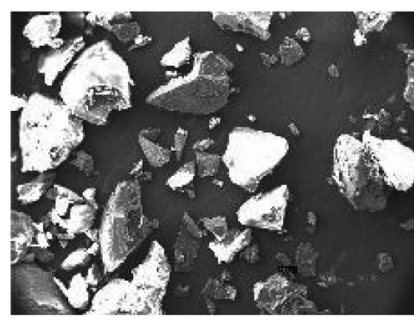

L

Fig. 1. Scanning electron micrographs of brown rice starches. A: Ilpumbyeo polished rice, B: Fry popped Ilpumbyeo polished rice, C: Hwaseonchalbyeo brown rice, D: Fry popped Hwaseonchalbyeo brown rice, E: Baegjinju brown rice, F: Fry popped Baegjinju brown rice, G: Ilpumbyeo brown rice, H: Fry popped Ilpumbyeo brown rice, I: Goami brown rice, J: Fry popped Goami brown rice, K: Air popped Ilpumbyeo brown rice, L: Parboiled-Air popped Ilpumbyeo brown rice

튀김 쌀의 색도

무처리 현미, 분쇄된 현미 및 튀김 처리구의 색도를 측정한 결 과 Table 4에서 보는 바와 같이 분쇄된 현미가 L값에서 높은 수 치를 나타내어 밝은 색도를 나타냈으며, 화선찰벼의 $\mathrm{L}$ 값이 82.80 으로 가장 높은 결과를 보여주었다. $\mathrm{a}$ 값을 나타내는 적색도와 $\mathrm{b}$ 값을 나타내는 황색도는 Table 5, Table 6에서 보여주듯이 L값과 상반된 결과를 나타냈다. 현미상태 일품벼의 a값이 4.24, 일품벼 를 튀긴 후 a값이 4.41로 높은 수치를 나타냄으로서 일품벼가 다 른 품종에 비하여 상대적으로 적색도가 높은 것으로 나타났다.
품종별 현미를 수분함량별과 일품벼의 튀김 처리를 달리하여 색 도를 측정한 결과 Table 6과 같이 수침처리만 한 경우는 수분함 량이 증가할수록 $\mathrm{L}$ 값이 감소하는 경향을 나타내었고, $\mathrm{a}$ 값, $\mathrm{b}$ 값은 증가하는 경향을 나타내었다. 그리고, 수침 후에 호화 시킨 경우 는 수분함량이 증가할수록 $\mathrm{L}$ 값은 별다른 변화를 나타내지 않았 고, $a$ 값, $b$ 값은 수침처리만 한 경우와 비슷하게 증가하는 경향을 나타내었다. 이것은 $190^{\circ} \mathrm{C}$ 의 고온에서 튀김 처리를 하는 과정에 서 메일라드 반응에 기인하는 것으로 생각된다.

Table 4. Hunter values for 4 kinds of types powder brown rices

\begin{tabular}{|c|c|c|c|c|c|}
\hline & A & B & $\mathrm{C}$ & $\mathrm{D}$ & F-value \\
\hline $\mathrm{L}$ & $82.80^{\mathrm{a}} \pm 0.72$ & $80.82^{\mathrm{bc}} \pm 0.86$ & $79.20^{\mathrm{d}} \pm 0.84$ & $81.34^{\mathrm{b}} \pm 0.59$ & 2025.04 \\
\hline $\mathrm{a}$ & $0.42^{\mathrm{e}} \pm 0.10$ & $0.43^{\mathrm{e}} \pm 0.05$ & $0.85^{\mathrm{c}} \pm 0.10$ & $0.60^{\mathrm{d}} \pm 0.05$ & 1293.45 \\
\hline $\mathrm{b}$ & $10.28^{\mathrm{d}} \pm 0.22$ & $12.26^{\mathrm{a}} \pm 0.19$ & $11.88^{\mathrm{b}} \pm 0.27$ & $11.63^{\mathrm{c}} \pm 0.24$ & 5057.70 \\
\hline
\end{tabular}

A: Hwaseonchalbyeo, B: Baegjinju, C: Ilpumbyeo, D: Goami

Table 5. Hunter values for 4 kinds of types brown rices

\begin{tabular}{ccrrrr}
\hline & $\mathrm{A}$ & \multicolumn{1}{c}{$\mathrm{B}$} & \multicolumn{1}{c}{$\mathrm{C}$} & $\mathrm{D}$ & $\mathrm{F}$-value \\
\hline $\mathrm{L}$ & $59.58^{\mathrm{a}} \pm 1.73$ & $55.55^{\mathrm{b}} \pm 1.21$ & $48.70^{\mathrm{c}} \pm 7.99$ & $54.78^{\mathrm{b}} \pm 1.98$ & 95.99 \\
$\mathrm{a}$ & $1.29^{\mathrm{ab}} \pm 0.30$ & $1.43^{\mathrm{ab}} \pm 0.38$ & $4.24^{\mathrm{a}} \pm 7.64$ & $1.84^{\mathrm{ab}} \pm 0.21$ & 1.55 \\
$\mathrm{~b}$ & $13.44^{\mathrm{a}} \pm 0.41$ & $12.86^{\mathrm{a}} \pm 0.27$ & $12.30^{\mathrm{ab}} \pm 3.21$ & $12.15^{\mathrm{ab}} \pm 0.56$ & 137.27 \\
\hline
\end{tabular}

A: Hwaseonchalbyeo, B: Baegjinju, C: Ilpumbyeo, D: Goami 
Table 6. Effects of moisture content of brown rice of different rice cultivars on the Hunter color values of soaked, soaked-gelatinized, soak-air-popped, soaked-gelatinized-airpopped, soaked-fry popped or soaked-gelatinized-fry popped brown rice

\begin{tabular}{|c|c|c|c|c|c|c|c|c|c|c|c|}
\hline \multicolumn{12}{|c|}{ Hunter Value for 4 kinds of types brown rices } \\
\hline & M & Types & $\mathrm{L}$ & $\mathrm{a}$ & $\mathrm{b}$ & & M & Types & $\mathrm{L}$ & $\mathrm{a}$ & $\mathrm{b}$ \\
\hline $\mathrm{S}$ & $15 \%$ & A & 71.29 & 1.62 & 16.93 & G & $15 \%$ & $\mathrm{C}$ & 62.09 & 0.98 & 15.06 \\
\hline $\mathrm{S}$ & & $\mathrm{B}$ & 71.99 & 2.41 & 16.64 & G & & $\mathrm{D}$ & 59.97 & 1.97 & 16.36 \\
\hline $\mathrm{S}$ & & $\mathrm{C}$ & 68.60 & 2.71 & 18.38 & G & $25 \%$ & A & 58.83 & 0.13 & 11.54 \\
\hline $\mathrm{S}$ & & $\mathrm{D}$ & 69.90 & 2.91 & 19.18 & $\mathrm{G}$ & & B & 58.61 & 1.00 & 13.24 \\
\hline $\mathrm{S}$ & $20 \%$ & A & 72.06 & 0.68 & 15.98 & G & & $\mathrm{C}$ & 57.72 & 0.69 & 13.11 \\
\hline $\mathrm{S}$ & & B & 67.78 & 1.17 & 15.96 & $\mathrm{G}$ & & $\mathrm{D}$ & 60.75 & 0.91 & 13.89 \\
\hline $\mathrm{S}$ & & $\mathrm{C}$ & 68.11 & 1.16 & 16.30 & $\mathrm{G}$ & $35 \%$ & A & 59.11 & 0.53 & 12.43 \\
\hline $\mathrm{S}$ & & $\mathrm{D}$ & 66.57 & 1.24 & 16.15 & G & & B & 59.75 & 0.84 & 12.38 \\
\hline $\mathrm{S}$ & $25 \%$ & A & 71.83 & 0.85 & 16.43 & G & & $\mathrm{C}$ & 57.69 & 0.41 & 12.34 \\
\hline $\mathrm{S}$ & & B & 68.63 & 1.47 & 16.41 & $\mathrm{G}$ & & $\mathrm{D}$ & 59.77 & 0.37 & 13.04 \\
\hline $\mathrm{S}$ & & $\mathrm{C}$ & 68.94 & 1.27 & 17.17 & G & $45 \%$ & A & 62.32 & 0.43 & 13.63 \\
\hline $\mathrm{S}$ & & $\mathrm{D}$ & 66.64 & 1.89 & 17.06 & G & & B & 62.21 & 0.44 & 12.84 \\
\hline $\mathrm{S}$ & $30 \%$ & A & 67.52 & 0.94 & 15.49 & $\mathrm{G}$ & & $\mathrm{C}$ & 64.10 & 0.44 & 14.44 \\
\hline $\mathrm{S}$ & & B & 65.83 & 0.80 & 15.05 & G & & $\mathrm{D}$ & 60.52 & 0.04 & 13.59 \\
\hline $\mathrm{S}$ & & $\mathrm{C}$ & 65.13 & 1.20 & 14.49 & $\mathrm{~S}$ & Air popping & $\mathrm{C}$ & 54.54 & 5.19 & 12.84 \\
\hline $\mathrm{S}$ & & $\mathrm{D}$ & 65.63 & 0.80 & 14.73 & G & & $\mathrm{C}$ & 45.25 & 5.49 & 9.56 \\
\hline G & $15 \%$ & A & 60.61 & 0.84 & 13.67 & $\mathrm{~S}$ & Oil frying & $\mathrm{C}$ & 50.17 & 4.41 & 12.86 \\
\hline G & & B & 61.22 & 1.13 & 13.70 & $\mathrm{G}$ & & $\mathrm{C}$ & 54.24 & 4.05 & 13.40 \\
\hline
\end{tabular}

A: Brown Hwaseonchalbyeo, B: Brown Baegjinju, C: Brown Ilpumbyeo, D: Brown Goami, S: Soaking of water, G: Gelatinization, M: Moisture content

Table 7. Texture characteristics of soaked-air popped, soaked-fry-popped, soak-gelatinized-air popped, soak-gelatinized-fry popped brown rice of different rice cultivars

\begin{tabular}{|c|c|c|c|c|c|c|c|c|c|c|c|c|}
\hline & A & B & $\bar{C}$ & $\mathrm{D}$ & $\bar{E}$ & $F$ & $\mathrm{G}$ & $\mathrm{H}$ & $\mathrm{I}$ & $\mathrm{J}$ & $\mathrm{K}$ & $\mathrm{L}$ \\
\hline Strength $\left(\mathrm{g} / \mathrm{cm}^{2}\right)$ & 86.31 & 185.36 & 192.64 & 56.56 & 140.21 & 234.57 & 259.02 & 219.38 & 63.24 & 120.08 & 73.75 & 56.67 \\
\hline Hardness $\left(\mathrm{g} / \mathrm{cm}^{2}\right)$ & 31.13 & 74.86 & 103.92 & 12.48 & 84.58 & 106.84 & 130.90 & 132.90 & 12.87 & 106.11 & 17.88 & 9.92 \\
\hline Adhesivness (g) & 9.74 & 37.75 & 16.12 & 2.61 & 26.11 & 48.38 & 128.93 & 67.97 & 11.39 & 41.55 & 14.16 & 6.97 \\
\hline Cohesivness (\%) & 39.27 & 39.48 & 35.92 & 7.55 & 34.64 & 79.56 & 126.47 & 70.74 & 14.63 & 100.41 & 20.22 & 9.05 \\
\hline Gumminess (g) & 0.32 & 2.04 & 0.72 & 0.08 & 0.80 & 2.40 & 6.32 & 2.38 & 0.37 & 0.58 & 0.45 & 0.24 \\
\hline Brittleness (g) & 0.60 & 2.77 & 0.78 & 0.06 & 0.61 & 4.14 & 16.56 & 2.94 & 0.34 & 0.82 & 0.51 & 0.17 \\
\hline
\end{tabular}

A: Parboiled-Fry popped Hwaseonchalbyeo brown rice, B: Parboiled-Fry popped Baegjinju brown rice, C: Parboiled-Fry popped Ilpumbyeo brown rice, D: Parboiled-Fry popped Goami brown rice, E: Fry popped Hwaseonchalbyeo brown rice, F: Fry popped Baegjinju brown rice, G: Fry popped Ilpumbyeo brown rice, H: Fry popped Goami brown rice, I: Air popped Ilpumbyeo brown rice, J: Parboiled-Air popped Ilpumbyeo brown rice, K: Extrusioned-Fry popped Ilpumbyeo brown rice, L: Extrusioned-Parboiled-Fry popped Ilpumbyeo brown rice

\section{튀김 쌀의 조직}

Table 7에서는 제품의 조직감에 대한 측정 결과를 나타내었다. 강도는 $\mathrm{F}, \mathrm{G}$ 가 $234.57,259.02 \mathrm{~g} / \mathrm{cm}^{2}$ 으로 가장 높은 값을 나타내 었고, 경도에서는 $\mathrm{G}, \mathrm{H}$ 가 $130.90,132.90 \mathrm{~g} / \mathrm{cm}^{2}$, 응집성에서는 $\mathrm{G}$, $\mathrm{J}$ 가 $126.47,100.41 \%$ 로 각 각 높은 측정결과를 보여주었다. 부서 짐성에서도 $\mathrm{G}$ 가 $16.56 \mathrm{~g}$ 으로 가장 높은 결과를 보이며 가장 잘 부서지는 것으로 나타났다. 수침 후 파보일링 처리로 강도와 경 도는 더 높은 것으로 나타났으나 부서짐성에서는 상반된 결과를 보여주었다. 품종에서는 일품벼가 가장 강도와 경도가 큰 것으로 나타났고, 뻥튀기 처리구가 상대적으로 튀김 처리구 보다 강도와 경도에서는 약한 결과를 보여주었으나 부서짐성에서는 유사한 결 과를 나타냈다.

\section{요 약}

아밀로오스 함량의 차이가 있는 품종별 현미를 대상으로 frying
처리와 파보일링 처리를 통해 품질 특성을 조사하였다. 품종별 현미의 용융 흡열 곡선을 관찰한 결과 amylose 함량이 증가할수 록 호화 엔탈피가 감소되는 경향이 관찰되었으며, amylograph 측 정결과 현미 중 효소의 불활성화를 위해 $\mathrm{HgCl}_{2}$ 처리와 전분입자 의 팽윤정도에 따라 영향을 미치는 것을 확인할 수 있었다. Gelatinization temperature는 Ilpumbyeo가 가장 높은 것으로 나타 났으며, Goami가 maximum viscosity와 breakdown 값이 가장 높 은 수치를 보여주었다. X-선 회절도 분석 결과 일품벼 백미의 경 우 결정형이 소실된 $\mathrm{V}$ 형, 일품벼 현미의 경우 $\mathrm{B}$ 형의 결정체에 가까운 것이 관찰되었다. 가공처리에 따른 주사전자현미경 측정 결과 파보일링 처리 후 튀긴 경우 amylose 함량이 높을수록 표 면이 둥근 형태를 띠는 것을 확인할 수 있었다. 또한, 수침 후 파보일링 처리 후 튀긴 경우가 수침처리만 한 후 튀긴 경우보다 전체적으로 강도와 경도 측정결과 더 높은 것을 확인 할 수 있 었다. 


\section{References}

1. Juliano BO, Bechtel DB. The rice grain and its gross composition. pp. 77-107. In: Rice: Chemistry and Technology. Champagne ET. The American Association of Cereal Chemists, Inc., Minesota, MN, USA (1985)

2. Han GJ, Lee HY, Park HJ, Park YH, Cho YS. Cooking technique developoment to improve the taste of cooked rice: -A consumer survey on purchasing rice and cooked rice consumption-. Korean J. Food Cookery Sci. 23: 452-460 (2007)

3. Lee MS, Cho EJ. Cooking Characteristics and Firming Rate of Cooked Parboiled Rice. Korean J. Soc. Food Sci. 12: 46-53 (1996)

4. Ali SZ, Bhattacharta KR. Hydration and amylose solubility behavior parboiled rice. Le-bensm. Wiss. Technol. 5: 207-212 (1972)

5. Stevenson SG, Vasey-Genser M, Eskin NAM. Quality control in the use of deep frying oils. J. Am. Oil Chem. Soc. 61: 1102-1108 (1984)

6. Kim MS, Yang HR, Jeong YH. Mineral Contents of Brown and Milled Rice. J. Korean Soc. Food Nutr. 33: 443-446 (2004)

7. Firestone D, Horwitz W, Friedman L, Shue GM. Heated fats. I. Stedies of the effects of heating on the chemical nature of cotton- seed oil. J. Am. Oil Chem. Soc. 38: 253-257 (1961)

8. Shin DH, Kim MK, Chung TK, Lee HY. Quality characteristics of yukwa (Popped rice snack) made by different varieties of rice. Korean J. Food Sci. Technol. 21: 820-825 (1989)

9. Johnson OC, Sakuragi T, Kummerow FA. A comparative study of the nutritive value of thermally oxidized oils. J. Am. Oil Chem. Soc. 33: 433-435 (1956)

10. Shibuya $\mathrm{N}$. Effect of $\alpha$-amylase on the amylogram of milled rice flour. J. Jpn. Soc. Starch Sci. 30: 284-287 (1983)

11. AACC. Approved Method of the AACC. Sec. 10-22. American Association of Cereal Chemists, St. Paul, MN, USA (1985)

12. Anderson RA. Water absorption and solubility and amylograph characterisrics of roll-cooked small grain products. Cereal Chem. 59: 265-269 (1982)

13. Biliaderis CG, Page CM, Maurice TJ, Juliano BO. Thermal characterization of rice starches, A polymeric approach to phase transitions of granular starch. J. Agr. Food Chem. 34: 6-14 (1986)

14. Damir. Comparative studies on the physicochemical properties and microstructure of raw and parboiled rice. Food Chem. 16: 114 (1985)

15. Kim HS, Moon SJ, Sohn KH, Heu MH. Cooking properties of waxy varieties of rice. Korean J. Food Sci. Technol. 9: 144-152 (1977) 